\title{
Chapter 11 \\ Article 16: The Right to Protection \\ of Privacy
}

\author{
Christian Whalen
}

1. No child shall be subjected to arbitrary or unlawful interference with his or her privacy, family, home or correspondence, nor to unlawful attacks on his or her honour and reputation.

2. The child has the right to the protection of the law against such interference or attacks.

\section{What Did Children Say?}

Parents and housemothers (in state care facilities) should ask if they can check your personal stuff because you sometimes don't want them to see the stuff. They should not read our diaries and not answer our phone calls. (Africa)

Government should pass a law banning unnecessary surveillance on the children. (Asia-Pacific)

The opportunity to be online and have a chat without fear of disclosure of chat and correspondence. (Eastern Europe)

Training for students as to how to protect their privacy in social media, and the impact of data mining. (Eastern Europe)

C. Whalen (西)

Office of the Child, Youth and Seniors Advocate, Fredericton, NB, Canada

e-mail: Christian.Whalen@gnb.ca 


\section{Overview}

Article 16 asserts the child's right to privacy in the exact terms of the International Covenant on Civil and Political Rights, but it innovates by juxtaposing this right to a new right in relation to the child's right to information in Article 17. ${ }^{1}$ Protecting privacy in an information age requires a principled regulation of a child's right to access information that can promote their social, spiritual and moral development. The nexus between Articles 16 and 17 is therefore an important one. The Travaux Préparatoires reveal that the first drafts of the Convention included no provision on a right to privacy (Detrick et al., 1992, pp. 255-265). A draft provision was introduced by the United States 1982 stating: 'that the child and his parents are not subject to unlawful or arbitrary interference'. In 1983, the United States tried again to incorporate a right to privacy referencing only the child's right and not the parents' rights and in 1985, further recommended that the right to privacy be couched in a broader provision of civil and political rights generally. Eventually, it was agreed to include the right, as with other civil and political rights, following the text of the International Covenant on Civil and Political Rights as faithfully as possible.

Article 16 affirms the child's right to privacy, including informational privacy, personal and spatial privacy, and the right to solitude ${ }^{2}$; it also emphasises a right to protection against arbitrary or unlawful interference with the child's family, home or correspondence $^{3}$; and a right to protect his or her honour and reputation. ${ }^{4}$ Finally, the Article requires States Parties to protect children legally from interference or attacks on their privacy. Children's privacy can be particularly at risk within their parental home, within alternative care settings, and within institutional settings including schools and hospitals. ${ }^{5}$ However, as for adults, children's privacy is increasingly at risk online (Innocenti, 2012). Threats to children's privacy may arise from the digital

\footnotetext{
${ }^{1}$ For a discussion in relation to the links between the right to privacy and the right to information more generally, see David Banisar's The Right to Information and Privacy: Balancing Rights and Managing Conflicts (2011).

${ }^{2}$ Prosser defined privacy as encompassing four basic rights of (1) a right to solitude; (2) protection from public disclosure of embarrassing facts; (3) protection from publicity placing one in a false light; and (4) protection from appropriation of one's name or likeness (1960). Cf Alan Westin, Privacy and Freedom (1967), who defined the four states of privacy as solitude, intimacy, anonymity and reserve.

${ }^{3}$ In reference to child privacy in institutional settings, see Niamh Joyce, An Analysis of the Extent of the Juvenile Offender's Right to Privacy: Is the Child's Right to Privacy Circumvented by Public Interest? (2011); regarding violations of a child's privacy at home and for the philosophical underpinnings of Article 16 see Joel Feinberg, 'The Child's Right to an Open Future' (1980).

${ }^{4}$ Libel and slander laws must protect children as well, and the Committee has expressed concern not merely about the application of these laws in individual cases but also to the treatment of children in general by the media (1996).

${ }^{5}$ The Committee interprets family, home and correspondence broadly, to encompass all relatives and significant persons living in familial contact with the child, every domicile or place of residence which a child may call home, and all forms of communication in which the child may have a privacy interest (Hodgkin et al., 2007, p. 210; UN Committee on the Rights of the Child, 2006, para. 15).
} 
activities of others, whether peers, family, educators or strangers; from data collection and processing by public institutions, businesses and other organisations; and from criminal activities such as hacking and identity theft (Innocenti, 2017). The Committee has pointed out the significant rise in the range and incidence of privacy concerns related to the increase in mass collection of personal data and the multiplication of platforms for sharing of such data (UN Committee on the Rights of the Child, 2014 and 2021). While the text of the Convention directly reflects the formulation of the right to privacy in the ICCPR, the provision is also supple enough to defend children's privacy against the emergent threats of state surveillance and exploitative commerce.

\section{General Principles}

Article 2 The relationship between privacy rights and liberty interests, for instance those in Articles 6, 12, and 13 through to 17, is stronger than with equality interests and yet privacy rights of children intersect with the non-discrimination principle in Article 2 in important ways. For example, marginalised and vulnerable children, such as visible minorities, children with disabilities, LGBTQ children, and street or drug-endangered children may find themselves more often in institutional settings where their privacy rights may be infringed and may be particularly susceptible to privacy rights violations in those settings.

Article 3 The best interests of the child principle may at times be mistakenly invoked as a justification for breaching a child's privacy. Privacy interests are sometimes considered trivial, ${ }^{6}$ a right that state officials may view as something to be overridden when the child's best interests require it. The Committee, however, has sought to dissuade governments from this view and has insisted that the best interests principle has to be applied in a manner consistent with the provisions of the Convention as a whole (2007, para. 26).

Article 6 The relationship between the child's right to life, survival, and maximum development, and the right to privacy, is a close one. The framers of the Convention were concerned that a strong right to privacy might infringe on parental authority, and accordingly, the provision initially included a limitation to safeguard parental authority. That limitation was eventually removed and recast as Article 5 (Detrick et al., 1992, pp. 258-259). The Convention balances the parents' role in nurturing

\footnotetext{
${ }^{6}$ The history of the evolution of privacy law as a common law tort both in the U.S. and in commonwealth jurisdictions shows how reluctant courts have been to engage in resolving privacy disputes. Lord Denning's flat denial of a tort of invasion of privacy in Re X a Minor, [1975] 1 All ER 697, is premised on the view that the law does not concern itself with trifles and that privacy violations are best regulated through norms and social conventions. Lawrence Lessig, like most American constitutional scholars, takes a different view and demonstrates how in an information age privacy must be protected as a foundational human rights norm (2006).
} 
and guiding the child in the exercise of their rights, in a manner consistent with the child's evolving capacities, against the child's autonomy and liberty interests. The right to life, survival, and development are the kernel of the child's liberty interests in contributing to the child's development into an autonomous human being. Protecting the child's privacy is a critical factor in developing their autonomy, freedom, and agency.

Article 12 The child's right to express their views must be understood as a right, not an obligation (UN Committee on the Rights of the Child, 2009, para. 16). Children can choose not to express themselves, and in so doing are exercising a right to privacy. When children do express their opinions and views in decisions affecting them, they are entitled to a reasonable expectation of privacy. ${ }^{7}$ For example, in health consultations, in decisions concerning placement in care, or concerning their experience as victims of abuse or neglect, there should be a presumption of confidentiality but with limits, linked to the child's right to protection, consideration of their best interests, and parental rights in relation to the upbringing of their children (Tobin \& Field, 2019, pp. 570-571). Any decision to override the right to privacy or confidentiality must be informed by both evidence and the views of the child themselves. In court proceedings, the balancing of the child's right to privacy with the interests of fairness and due process in decision-making should always be carried out with regard for the child's best interests. ${ }^{8}$

\section{Articles Related or Linked to Article 16}

Article 5 provides that appropriate direction and guidance by parents and guardians must be consistent with the child's evolving capacities and, accordingly, must take account of their privacy rights in line with those capacities.

Article 7 which provides the right to a name, nationality and to know one's parents can, in certain circumstances, raise a conflict of interest between the privacy rights of the child and their parents.

Article 8, preservation of identity is integral to the child's protection of their privacy and sense of family and belonging.

Article 9, non-separation from parents unless in the child's best interests, but where such separation is necessary, it is imperative that in any proceedings, children's privacy is fully respected.

\footnotetext{
${ }^{7}$ In the context of criminal justice administration, confidentiality requirements are explicitly spelled out in the convention Article 40(2) (vii) and in the Committee's General Comments, for example General Comment no. 12, paragraph 61, but the nexus between Articles 12 and 16 is often in play in mental health and child protection proceedings as well (Hodgkin et al., 2007, p. 203).

${ }^{8}$ See, for example, A.B. v. Bragg Communications Inc. [2012] 2 S.C.R. 567, a case from the Supreme Court of Canada dealing with the balancing of a child's privacy interests with the demands of fairness in relation to the open court rule.
} 
Article 13 provides for children's right to freedom of expression, but this is limited by the requirement that it is exercised in accordance with respect for the rights or reputations of others.

Article 17 provides for children's rights to information from the mass media, but such information must not violate child privacy rights.

Article 19 provides protection from violence but in any intervention to provide protection, the child's privacy rights must be respected.

Article 20, children in alternative forms of care must have their privacy rights respected.

Article 37 imposes a prohibition on cruel or unusual punishment and arbitrary deprivation of liberty, and where punishment or deprivation of liberty is imposed it must not violate children's privacy rights.

Article 40, children's privacy must be respected within the criminal justice system.

\section{Relevant Instruments}

UN Universal Declaration of Human Rights (1948), Article 12

International Covenant on Civil and Political Rights (1966), Article 17

European Convention on Human Rights (1950), Article 8

American Convention on Human Rights 'Pact of San Jose, Costa Rica' (B-32) (1978), Article 11

African Charter on the Rights and Welfare of the Child (1990), Article 10

\section{Attributes}

\section{Attribute One: Interference with Privacy}

Privacy is vital for children's agency, dignity and safety, and for the exercise of their rights (Innocenti, 2017; Kaye and UN Human Rights Council, 2018; UN General Assembly, 2019). One of the core values protected by the right to privacy is the right to be left alone, or the right to solitude. Janusz Korczak, for example, highlighted that even children in an orphanage, with dormitories and very limited privacy, needed a private space, be it a drawer or a suitcase to keep their more prized possessions, a place that would be only theirs $\left(2009\right.$, p. 25). ${ }^{9}$ Courts sometimes

\footnotetext{
${ }^{9}$ The Human Rights Committee also describes this right to solitude when it insists that 'competent public authorities should only be able to call for such information relating to an individual's private life the knowledge of which is essential in the interests of society': (United Nations, 2006, p. 18).
} 
distinguish personal privacy from informational or spatial privacy. ${ }^{10}$ The closer an intrusion comes to the biographical core of a child's privacy, the higher the onus against interference will be. National constitutional courts and regional human rights bodies have developed a clear jurisprudence in relation to privacy rights, placing strict limits on state intrusions on a child or any citizen's privacy. They insist that the law must protect against privacy infringements that are:

- not sanctioned by law

- arbitrary (in the sense that they must be carried out in the pursuit of legitimate state aims)

- unnecessary. It must be shown that the privacy infringement was not disproportionate to the legitimate aims sought and constituted the least intrusive means of securing those legitimate aims (Electronic Frontier Foundation, 2014).

The Convention also requires that States Parties take measures to protect children's privacy from intrusion by non-state actors. Violations of a child's intimacy, through relentless bullying, luring, and unwanted attention or touching infringe Article 16 (UN Committee on the Rights of the Child, 2014). Similarly, non-consensual collection of a child's biological data, through blood samples, voiceprints, and fingerprints may constitute infringements (Global Privacy Assembly, 2008). Consent-based schemes for the collection of such data may also infringe on privacy. ${ }^{11}$ Threats to privacy are often online. Data mining and targeted marketing to children based upon their online web-surfing activities, and the use of embedded sensors in toys and clothes connected to automated systems, often lack transparency and may constitute violations of the child's right to be let alone (Milkaite \& Verdoodt, 2017). School video surveillance also intrudes upon children's privacy and can only be justified if the interference is neither unlawful or arbitrary (Information and Privacy Commissioner of Ontario, 2015; Office of the Privacy Commissioner of Canada, 2012).

\section{Attribute Two: Interference with Family, Home, or Correspondence}

Article 16 also deals with spatial or territorial privacy and informational privacy which is given a very broad reading by the Committee, as it is in other constitutional law texts and human rights treaties (Hodgkin et al., 2007, pp. 210-211). The text is broad enough to encompass a trespass to property or to a family member, and

\footnotetext{
${ }^{10}$ For example, see R. v. Dyment [1988] 2 S.C.R. 417 (http://canlii.ca/t/1ftc6) and R. v. Plant [1993] 3 S.C.R. 281 (http://canlii.ca/t/1fs0w)

${ }^{11} \mathrm{As}$, for instance, when young internauts provide online consent to unscrupulous internet service providers or online game services through privacy policies that take unfair advantage or are couched in terms that children will not clearly understand (Lawford et al., 2008, p. 19).
} 
although the Convention does not establish property rights for children, the privacy protections do afford children a certain right to exclusive enjoyment of their property and protection against the interference of others (Kilkelly, 2001, pp. 59-62). It also protects their relationships with family. For example, attempts at alienating a child from one of their parents or siblings could constitute a privacy rights violation (Kilkelly, 2001, pp. 50-54). In jurisdictions subject to the European Convention on Human Rights, the privacy rights of children are frequently invoked in child protection matters. However, most privacy infractions today are in relation to informational privacy, and increasingly in respect of the digital environment, for example, breaches of confidentiality, personal health information leaks, and surveillance. In many cases, intrusions into children's personal information that would be unacceptable for adults are justified for children in terms of their protection and best interests. However, any such intrusions must be valid and justified taking into account children's own views and their evolving capacities (Tobin \& Field, 2019, p. 570).

\section{Attribute Three: Unlawful Attacks on Honour and Reputation}

Privacy experts maintain that we are moving from an information age to an economy founded on reputation (Lessig, 2010; Swallow, 2013). Article 16 rights protect children from traditional harms such as libel, slander, and misappropriation of their image. The Committee, for example has pointed to the vulnerability of street children to unlawful attacks on their honour and reputation (2017, paras. 27, 43, 60). The Committee has also argued that children's honour and reputation can also be abused as a group, for example, by the media denigrating them and their behaviour based merely on their age. ${ }^{12}$ However, in the age of social media, where children are increasingly engaged in activities without parental supervision, children are particularly at risk of various online risks to the honour and reputation (Nyst, 2017). Increasingly the attacks on honour and reputation come in the form of distribution of sexts, cyber-bullying, child pornography and the unauthorised use of children's images online.

In order to constitute a violation, an attack must be intentional and contain untruthful statements (Tobin \& Field, 2019, p. 594). The Human Rights Committee has argued that States Parties have to balance the rights embodied in Article 16 with the right to freedom of expression, but at the same time they also have an obligation to enable individuals to protect themselves from unlawful attacks and to have an effective remedy against those responsible (UN Human Rights Committee, 2011, para. 37; United Nations, 2006, p. 181).

\footnotetext{
${ }^{12}$ See, for example, Concluding Observations for Nicaragua (UN Committee on the Rights of the Child, 1995, paras. 17, 34).
} 


\section{Attribute Four: Protection of the Law Against Unlawful Interference or Attacks}

Data monitoring and measurement of child privacy standards requires more than the simple proclamation of the rights to privacy. There must also be programmes to dissuade the public from these practices, to sanction them, and to provide recourses and remedies to victims of bullying and other privacy violation (United Nations, 2006, p. 182). Surveillance of children, together with any associated automated processing of personal data, must not be conducted routinely or indiscriminately, and not without children's knowledge (UN General Assembly, 2019). States Parties should review their own procedures regarding the collection and processing of children's personal data and correspondence to ensure they respect children's right to privacy, including in governmental decision-making and within the criminal justice system (UN General Assembly, 2019). Furthermore, any restrictions or intrusions on the child's right to privacy must be prescribed by law, necessary, and proportionate (UN Human Rights Council, 2017, para. 2; UN Office of the High Commissioner for Human Rights (OHCHR), 2014, para. 23). States Parties should also ensure the implementation of effective data protection legislation, and take other measures as necessary, to prevent arbitrary or unlawful interference with children's privacy, family, home or correspondence in relation to the digital environment (Albania et al., 2018; Nyst, 2017; UN General Assembly, 2019).

\section{References}

Albania, Argentina, Australia, Austria, Belgium, Bosnia and Herzegovina, et al. (2018). The promotion, protection and enjoyment of human rights on the Internet: Draft resolution, 2018, A/HRC/38/L.10/Rev.1. UN. Retrieved October 25, 2020, from http://digitallibrary.un.org/ record/1639844

Banisar, D. (2011). The right to information and privacy: Balancing rights and managing conflicts (SSRN Scholarly Paper No. ID 1786473). Social Science Research Network. https://doi.org/10. 2139/ssrn. 1786473

Detrick, S., Doek, J. E., \& Cantwell, N. (1992). The United Nations convention on the rights of the child: A guide to the "Travaux Préparatoires." Martinus Nijhoff Publishers.

Electronic Frontier Foundation. (2014). Necessary \& proportionate: International principles on the application of human rights to communications surveillance. https://www.ohchr.org/ Documents/Issues/Privacy/ElectronicFrontierFoundation.pdf

Feinberg, J. (1980). The child's right to an open future. In W. Aiken \& H. Lafollette (Eds.), Whose child? Children's rights, parental authority, and state power (pp. 124-153). Littlefield Adams.

Global Privacy Assembly. (2008). Resolution on children's online privacy-Adopted at the 30th international conference for data protection and privacy commissioners-Strasbourg, France 2008. Retrieved October 25, 2020, from http://globalprivacyassembly.org/wp-content/uploads/ 2015/02/Resolution-on-Childrens-Online-Privacy-.pdf

Hodgkin, R., Newell, P., \& UNICEF. (2007). Implementation handbook for the convention on the rights of the child (3rd ed.). UNICEF. Retrieved September 21, 2020, from https://digitallibrary. un.org/record/620060? $\mathrm{ln}=\mathrm{en}$ 
Information and Privacy Commissioner of Ontario. (2015). Guidelines for the use of video surveillance. Retrieved October 25, 2020, from https://www.ipc.on.ca/wp-content/uploads/ Resources/2015_Guidelines_Surveillance.pdf

Joyce, N. (2011). An analysis of the extent of the juvenile offender's right to privacy: Is the child's right to privacy circumvented by public interest? European Journal of Crime, Criminal Law and Criminal Justice, 19(2), 113-124. https://doi.org/10.1163/157181711X566335

Kaye, D., \& UN Human Rights Council. (2018). Promotion and protection of the right to freedom of opinion and expression: Report of the Special Rapporteur, A/73/348. UN. Retrieved October 24, 2020, from http://digitallibrary.un.org/record/1643488

Kilkelly, U. (2001). The right to respect for private and family life: A guide to the implementation of Article 8 of the European Convention on Human Rights (2003). : Council of Europe Publishing. Retrieved October 25, 2020, from https://rm.coe.int/090000168007ff47

Korczak, J. K. (2009). Janusz Korczak: The child's right to respect-Lectures on today's challenges. Council of Europe Publishing. https://rm.coe.int/09000016807ba985

Lawford, J., Taheri, M., \& Public Interest Advocacy Centre (Canada). (2008). All in the data family: Children's privacy online. Retrieved October 25, 2020, from http://epe.lac-bac.gc.ca/100/200/ 300/public_interest_advocacy/children_final/children_final_small_fixed.pdf

Lessig, L. (2006). Code: And other laws of cyberspace, version 2.0. Basic Books.

Lessig, L. (2010, January 17). Sharing economies. The Mindful Word. Retrieved October 25, 2020, from https://www.themindfulword.org/2010/sharing-economies-lawrence-lessig

Milkaite, I., \& Verdoodt, V. (2017). The general data protection regulation and children's rights: Questions and answers for legislators, DPAs, industry, education, stakeholders and civil society. Better Internet for Kids. Retrieved October 25, 2020, from https://www. betterinternetforkids.eu/documents/167024/2013511/GDPRRoundtable_June2017_FullReport. pdf

Nyst, C. (2017). Privacy, protection of personal information and reputation rights. UNICEF. https://www.unicef.org/csr/css/UNICEF_CRB_Digital_World_Series_PRIVACY.pdf

Office of the Privacy Commissioner of Canada. (2012). Surveillance technologies and children. Retrieved October 25, 2020, from https://www.priv.gc.ca/media/1751/opc_201210_e.pdf

Prosser, W. L. (1960). Privacy. California Law Review, 48(3), 383-423. https://doi.org/10.2307/ 3478805

Swallow, E. (2013, October 9). The rise of the reputation economy. Forbes. Retrieved October 25, 2020, from https://www.forbes.com/sites/ericaswallow/2013/10/09/reputation-economy/

Tobin, J., \& Field, S. M. (2019). Article 16: The right to protection of privacy, family, home, correspondence, honour, and reputation. In J. Tobin (Ed.), The UN convention on the rights of the child: A commentary (pp. 551-599). Oxford University Press.

UN Committee on the Rights of the Child. (1995). Concluding observations: Nicaragua, June 20, 1995, CRC/C/15/Add.36. Retrieved October 11, 2020, from https://digitallibrary.un.org/ record $/ 191818 ? \ln =$ en

UN Committee on the Rights of the Child. (1996). Day of general discussion: The child and the media. UN. Retrieved October 25, 2020, from https://www.ohchr.org/EN/HRBodies/CRC/ Pages/DiscussionDays.aspx

UN Committee on the Rights of the Child. (2006). General Comment No. 7 (2005) Implementing child rights in early childhood, September 20, 2006, CRC/C/GC/7/Rev.1. Retrieved October 12, 2020, from https://digitallibrary.un.org/record/584854? $\ln =\mathrm{en}$

UN Committee on the Rights of the Child. (2007). General Comment No. 8 (2006) The right of the child to protection from corporal punishment and other cruel or degrading forms of punishment (arts. 19; 28, para. 2; and 37, inter alia), March 2, 2007, CRC/C/GC/8. Retrieved October 12, 2020, from https://digitallibrary.un.org/record/583961? $\ln =\mathrm{en}$

UN Committee on the Rights of the Child. (2009). General Comment No. 12 (2009) The right of the child to be heard, July 20, 2009, CRC/C/GC/12. Retrieved October 12, 2020, from https:// digitallibrary.un.org/record/671444? $1 \mathrm{n}=\mathrm{en}$ 
UN Committee on the Rights of the Child. (2014). Day of general discussion: Digital media and children's rights. UN. Retrieved October 24, 2020, from https://www.ohchr.org/EN/HRBodies/ CRC/Pages/Discussion2014.aspx

UN Committee on the Rights of the Child. (2017). General Comment No. 21 (2017) on children in street situations, June 21, 2017, CRC/C/GC/21. Retrieved October 12, 2020, from https:// digitallibrary.un.org/record/1304490? $\ln =\mathrm{en}$

UN Committee on the Rights of the Child. (2021). General Comment No. 25 (2021) on children's rights in relation to the digital environment. https://tbinternet.ohchr.org/_layouts/15/ treatybodyexternal/Download.aspx?symbolno $=\mathrm{CRC} \% 2 \mathrm{fC} \% 2 \mathrm{fGC} \% 2 \mathrm{f} 25 \& \mathrm{Lang}=\mathrm{en}$

UN General Assembly. (2019). The right to privacy in the digital age: Resolution adopted by the General Assembly, 2019, A/RES/73/179. UN. Retrieved October 25, 2020, from http:// digitallibrary.un.org/record/1661346

UN Human Rights Committee. (2011). CCPR General Comment No. 34 (2011) Article 19, Freedoms of opinion and expression, September 12, 2011, CCPR/C/GC/34. https://digitallibrary.un. org/record/715606? $\ln =$ en

UN Human Rights Council. (2017). The right to privacy in the digital age: Resolution adopted by the Human Rights Council on 23 March 2017, A/HRC/RES/34/7. UN. Retrieved October 25, 2020, from http://digitallibrary.un.org/record/1307661

UN Office of the High Commissioner for Human Rights (OHCHR). (2014). The right to privacy in the digital age: Report of the Office of the United Nations High Commissioner for Human Rights, 2014, A/HRC/27/37. UN. Retrieved October 25, 2020, from http://digitallibrary.un.org/ record/777869

UNICEF Office of Research, Innocenti. (2012). Child safety online: Global challenges and strategies. Technical report. Retrieved October 25, 2020, from https://www.unicef-irc.org/ publications/652-child-safety-online-global-challenges-and-strategies-technical-report.html

UNICEF Office of Research, Innocenti. (2017). Child privacy in the age of web 2.0 and 3.0: Challenges and opportunities for policy. Retrieved October 25, 2020, from https://www.unicefirc.org/publications/926-child-privacy-in-the-age-of-web-20-and-30-challenges-and-opportuni ties-for-policy.html

United Nations. (2006). Compilation of general comments and general recommendations adopted by human rights treaty bodies, HRI/GEN/1/Rev. 8. UN. Retrieved April 19, 2020, from http:// digitallibrary.un.org/record/576098

Westin, A. F. (1967). Privacy and freedom. Atheneum.

Open Access This chapter is licensed under the terms of the Creative Commons Attribution 4.0 International License (http://creativecommons.org/licenses/by/4.0/), which permits use, sharing, adaptation, distribution and reproduction in any medium or format, as long as you give appropriate credit to the original author(s) and the source, provide a link to the Creative Commons license and indicate if changes were made.

The images or other third party material in this chapter are included in the chapter's Creative Commons license, unless indicated otherwise in a credit line to the material. If material is not included in the chapter's Creative Commons license and your intended use is not permitted by statutory regulation or exceeds the permitted use, you will need to obtain permission directly from the copyright holder.

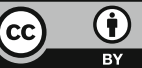

